DOI:10.2478/rrlm-2021-0013

\title{
Investigation of Apoptotic and Inflammatory Activity in Liver Tissue of Rats Fed with Clam (Pecten maximus, Linnaeus 1758)
}

\author{
Latife Ceyda İrkin* \\ Faculty of Applied Sciences Department of Fisheries Technology, Çanakkale Onsekiz Mart University, \\ Turkey
}

\begin{abstract}
One of the most important threats for living things in aquatic ecosystems is environmental pollution. The changes in water quality caused by environmental pollution also reduce the quality of life for organisms in the environment. Among these, the crustaceans which are most affected by the negative changes of environment, fed by the filtration method, are seen as pollution indicator. The consumption of these creatures reaches all steps of the pyramid, especially humans, through the food chain. People who frequently use seafood in their diets may be affected by these negative changes. Heavy metal contents of the clams obtained from Dardanelles were determined by the ICPOES. Twenty-four female Wistar albino rats were fed for 30 days with the experimental diet using clams (Pecten maximus), which was dried and formed into pellets and added to the food in certain proportions. At the end of the study, the subjects were sacrificed under anesthesia, liver tissues were taken, and histochemical examination was performed. TUNEL method was performed to detect apoptotic activity, and immunohistochemical staining with $T N F-\alpha$ and $N F-\kappa B$ antibodies to determine inflammation. Concluding from the results, it was observed that the degeneration of vital digestive system tissues such as liver was inevitable in living creatures that frequently consume seafood obtained from unhealthy environment in their daily diets. The high analysis values of the heavy metal ( $P$. maximus) in food additive can be considered as a reason for histopathological results.
\end{abstract}

Keywords: great clam, apoptosis, inflammation, liver, heavy metals

Received: $16^{\text {th }}$ December 2020; Accepted: 13 ${ }^{\text {th }}$ February 2021; Published: $24^{\text {th }}$ February 2021

\section{Introduction}

Bivalves have been reported as biomonitors of heavy metal contamination and are used to evaluate the pollution levels of coastal (1). As a result, bioaccumulation processes and heavy metal concentrations have been well characterized by studies conducted in these marine creatures. Thus, different uptake pathways and heavy metal bioaccumulations such as $\mathrm{Cd}$ (Cadmium) were determined in different physicochemical conditions of the environment (2-4). Bivalves are one of the protein source in diet and are an important

\footnotetext{
* Corresponding author: Latife Ceyda İrkin, Faculty of Applied Sciences Department of Fisheries Technology, Çanakkale Onsekiz Mart University, Turkey. E-mail: latifeirkin@gmail.com
} 
part of biogeochemical cycle in the aquatic areas as filters. Thus, bivalves accumulate heavy metals from water through filteration because of the feeding habits (5). Bivalves are also widely used in environmental pollution studies because of different tolerances to the pollution factors with different species $(2,6)$.

The emergence of toxic materials during chemical and industrial processes and their intensive use in agriculture can threaten the health of organisms. Organisms can face significant health problems by exposure to environmental pollutants directly from the digestive system and respiratory tract through the food chain (7). Metals should be in certain limit concentrations for enzymatic activities in organisms. Heavy metals can be taken by diverse ways that can be accumulated at different levels in organs and tissues. After participating in various metabolic pathways in the body, metals that can be expelled from the body, which have physiological importance. Conducting studies on the examination of heavy metal accumulation and damage in aquatic organisms is important to determine the species with high sensitivity to these metals as well as determining the biochemical, physiological, histological, structural, and functional disorders that may occur in the body. Metal ions have been found to interact with cell components such as DNA and nuclear proteins and cause conformational changes that can lead to DNA damage and cell cycle modulation, carcinogenesis, or apoptosis (8).

Since heavy metals are not found independently in aquatic environments, the number of studies examining the effects of heavy metal mixtures on aquatic organisms is increasing day by day. It will be understood what levels the metallic pollutants measured in living things as an indicator of environmental pollution can reach, especially in aquatic products, and the extent of their impact on the tissue, and whether these indicators create a risk factor for human health. The lack of information is particularly worrisome, as there is an ongoing debate about the extent to which the risks to human health are and whether such seafood will also be a source of contaminants for consumers $(9,10)$. For this reason, by this study we aimed to draw attention to the consumption of seafood from healthy and more reliable environments by showing the changes in the liver tissue with histochemistry and immunohistochemical techniques by feeding rats with an experimental in vivo nutrition model.

\section{Materials and Methods}

\section{Experimental groups}

WFor this study we used 24 male Wistar albino rats as subjects $(250 \pm 50 \mathrm{~g})$. Rats were kept at an average temperature of $22 \pm 2{ }^{\circ} \mathrm{C}$, humidity of $\% 55 \pm 5,12$ hours of light and 12 hours of darkness, with ventilation and air conditioning system. Adequate water was given to the rats. While feeding, a standard mixture of rat food and clams was given according to $15 \%$ of each rat's weight over thirty days. Experimental groups are as follows for thirty days:

- Control group (C): standard rat food,

- Group I (G1): 80\% clams, 20\% standard rat food everyday,

- Group II (G2): 80\% clams, 20\% standard rat food every two day,

- Group III (G3): 80\% clams, 20\% standard rat feed every three days.

At the end of the feeding phase of the experimental groups, the rats were anesthetized and the liver tissues were taken. Afterwards, the histochemical examination was performed. TUNEL method was performed to detect apoptotic activity. Immunohistochemical staining was performed with TNF- $\alpha$ and NF- $\kappa B$ antibodies to determine inflammation.

\section{Ethics Statement}

The study protocol was approved by the $\mathrm{Ca}$ nakkale Onsekiz Mart University Ethics Com- 
mittee for Animal Research (Protocol number: 2020/04-02).

\section{Experiment material collecting and preparing}

The aim of this experimental study was to determine the amount of heavy metals in bivalves and seawater, compare the bioaccumulation of toxic metals in seawater, and detect the relationship between heavy metal levels of bivalves and parameters of the seawater quality, to assess human health risk from heavy metal, and determine the maximum amount to be consumed by humans.

The study area for clams is located in the northwest region of Dardanelles (Lâpseki, Çardak, Çamburnu), on the west coast of Turkey. This areas are coastal towns and Dardanelles has important areas of the southwest coast of Marmara Region. The samples were collected in June 2019 from 10-40 m depth by scuba diving from the determined location. The samples were then dried in an oven at $60-65^{\circ} \mathrm{C}$ until a constant weight, following by grinding into powder. The samples were analyzed for Cadmium $(\mathrm{Cd})$, lead $(\mathrm{Pb})$, copper $(\mathrm{Cu})$, and zinc $(\mathrm{Zn})$ by inductively coupled plasma-optical emission spectrometry (ICP-OES). Sample preparation was performed using microwave-assisted acid digestion. The sample $(0.60 \pm 0.05 \mathrm{~g})$ was mixed with $8 \mathrm{ml}$ of $68 \%$ nitric acid and $4 \mathrm{ml}$ of $30 \%$ hydrogen peroxide. The system was heated to $120^{\circ} \mathrm{C}$ for about two hours. The solution was filtered with nitrocellulose membrane after cooling, and then transferred to acid-wash and made up to volume with deionized water.

\section{Microscopic examinations}

For this process, the liver tissues were fixed in $10 \%$ formalin for 2 days and the washing process started. Tissues were kept for 1 hour in alcohol $(70,90,96,100 \%)$. After the dehydration step, the tissues were treated with toluene for 3 sequences of 15 minutes for the clarification. Tissues were kept in soft paraffin overnight be- fore embedding. The next day, liver tissues were removed from soft paraffin and kept in liquid hard paraffin for 1 hour after which they were embedded in parrafin blocks. Sections of $5 \mu \mathrm{m}$ thick were taken from these blocks using a cylinder microtome. The sections were stained with $\mathrm{H} \& \mathrm{E}$ to reveal the histological and structural changes in the liver tissue.

\section{TUNEL method and apoptotic activity}

The Terminal Transferase dUTP Nick End Labeling (TdT Fragel DNA Fragmentation Kit) method was used to determine cell death. First, the sections were washed in distilled water and then with PBS solution for $3 \times 5$ minutes following the deparaffinization process. Subsequently, 20- $\mu \mathrm{g} /$ $\mathrm{ml}$ Proteinase-K diluted 1/500 with PBS solution was applied at room temperature for 15 minutes. After washing with PBS, the sections was treated with $3 \% \mathrm{H}_{2} \mathrm{O}_{2}$ for 5 minutes, and then washed again $3 \times 5$ min with PBS. The samples were kept at room temperature for 5 minutes with Equilibration buffer and then kept for 1 hour at $37^{\circ} \mathrm{C}$ in a humid environment with TdT-enzyme. At the end of an hour, the samples were treated with Stop Wash Buffer for 10 minutes, with Antidioxygenin Peroxidase Conjugate for 30 minutes and then washed $3 \times 5$ minutes with PBS again. They were then stained with DAB and washed with distilled water. Background was dyed with Mayer's Hematoxylin. TUNEL stainings were scored semi-quantitatively to determine the number of positive staining, none $(-)$, weak $(+)$, moderate $(++)$, high $(+++)$, very high $(++++)$. These analyses were performed in 2 sections for each animal, at a magnification rate of X 40 for at least 10 different regions per section $(11,12)$.

\section{Immunohistochemical staining with TNF- $\alpha$ and $N F-\kappa B$}

Immunohistochemical reactions were performed according to the $\mathrm{ABC}$ technique. Following this step, the sections were incubated with a 
polyclonal nuclear factor Kappa-B (NF- $\kappa \mathrm{B}$ $\mathrm{p} 50, \mathrm{ab} 323360)$, tumor necrosis factor (TNF- $\alpha$, ab194403), then the sections were incubated with biotinylated anti-mouse Immunoglobulin-G (DAKO LSAB 2 Kit, İnvitrogen). Following this step, they were stained with $\mathrm{ABC}$ complex and then with Mayer's Hematoxylin $(11,12)$.

\section{Statistical analysis}

During the assessment of the results, the immunoreactivity was evaluated with the H-score method, calculating the ratio of immunopositivity cells to all cells in the selected fields. Immunoreactive cell count was performed by a blinded observer and graded as follows: 0 denoted no staining; 1 denoted weak; 2 denoted moderate; 3 denoted strong staining in a specified field. The respective score was then calculated using the following formula:

$\mathrm{H}$-score $=(\%$ stained cells at 0$) \times 0+(\%$ stained cells at $1+) \times 1+(\%$ stained cells at $2+) \times 2$ $+(\%$ stained cells at $3+) \times 3$. The $\mathrm{H}$-score value ranges from 0 to 300 (13).

SPSS 19 version was used for statistical analysis. Data are expressed as mean $( \pm)$ standard deviation. The differences between the groups were evaluated by Kruskal-Wallis variance analysis. Mann-Whitney U test was used for comparisons between groups with significant differences. The difference was considered statistically significant if $\mathrm{p}<0.05$.

\section{Results and Discussion}

The control group liver tissue: No histopathological results of tumor cases were observed when liver tissue samples from rats fed with standard rat food every day stained with Hematoxylin and Eosin (Figure 1).

Experimental groups: The following histopathological results occurred in all experimental groups, respectively.
Vacuolar degeneration, focal necrosis, inflammatory cells including neutrophils and eosinophils in the lobule and portal area were detected. Vacuolar degeneration in most of the hepatocytes manifested by diffuse swelling, pale staining of the cytoplasm, and the appearance of the cytoplasmic residues around the nucleus. In addition, central, portal vein, and sinusoidal dilatation, congestion in portal veins were observed. These histophatological changes occurred more severely in the first group that had been given $80 \%$ clams and $20 \%$ standard rat food everyday. In other groups, liver damage decreased due to the ratio of clam and standard rat food mix (Figure 1).

\section{$N F-\kappa B$ and $T N F-\alpha$ results}

Immunohistochemical staining results obtained from this study showed that NF- $\kappa B$ and TNF- $\alpha$ expression had a higher immunoreactivity in the liver due to the increase in the G1 groups (daily clam feeding), and staining was largely in the cell cytoplasm. The apoptotic mechanism was found to be very high in the liver tissues, especially in the G1 group.

Immunohistochemical staining with NF- $\kappa \mathrm{B}$, positive immunoreactivity was observed in parallel with the consumption of clam food. In the G1 group, high reactivity was observed around the central vein. In the G2 and G3 groups, it was observed that the immunoreactivity around the central vein was moderate. A statistically significant difference was observed between the control and the G1 group of the subjects $(\mathrm{p}<0.0001)$ (Figure 2 and Figure 5 for NF- $\kappa \mathrm{B}$, Figure 3 and Figure 5 for TNF- $\alpha$ ).

\section{TUNEL results}

Apoptosis occurs in the disruption of oxidant-antioxidant balance and tissue damage in adult tissue is an important factor that triggers apoptosis. In hepatocellular damage, especially oxidative stress and inflammation, hepatocytes 

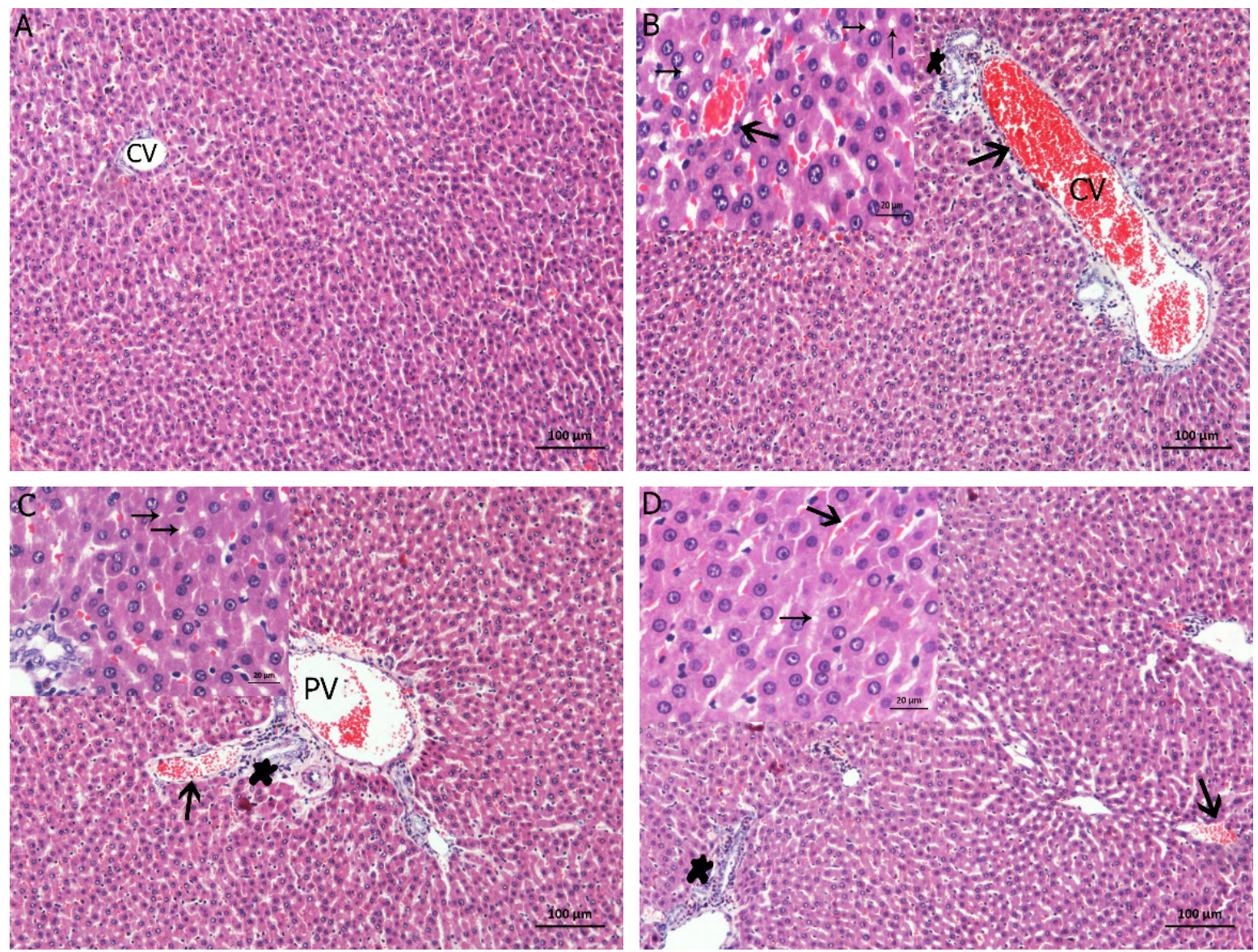

Fig. 1. A. Control group liver tissue, B- First experimental group (G1) liver tissue, C- Second experimental group (G2) liver tissue, D- Third experimental group (G3) liver tissue (magnification X10 and inner figures $\mathrm{X40}$, star: inflammation, thick arrow: congestion, thin arrow: vacuolar degeneration, CV: Central vein, PV: Portal vein).

drift into apoptosis by cytokines released from Kupffer cells. With the release of TNF- $\alpha$ from Kupffer cells, the apoptotic mechanism is activated and hepatocytes enter the apoptotic process. In the study of the experimental clam diet, it was observed that apoptosis was triggered in the liver tissues of the G1 group that had been fed clam diet per day and the cells leading to apoptosis increased these liver tissues. In TUNEL positivity, the highest significance among the groups was determined between the G1 and control group $(* * * * * p<0.00001)$, while the least significance was observed between the G3 and control group $(* * p<0.01)$. As a result, apoptotic index increases with the feeding of clam per day (Figure 4, Figure 5).

\section{Heavy metal analysis results}

According to the results, considering the $\mathrm{Cd}$, $\mathrm{Cu}, \mathrm{Pb}$, and $\mathrm{Zn}$ level in P. maximus, the location where the heavy metal concentration is high are Lâpseki and Çardak (Table 1). As heavy metal analysis results of the seawater from which the clam samples were taken, the values of the Lâpseki and Çardak region were found to be in parallel with the heavy metal values in the musc- 

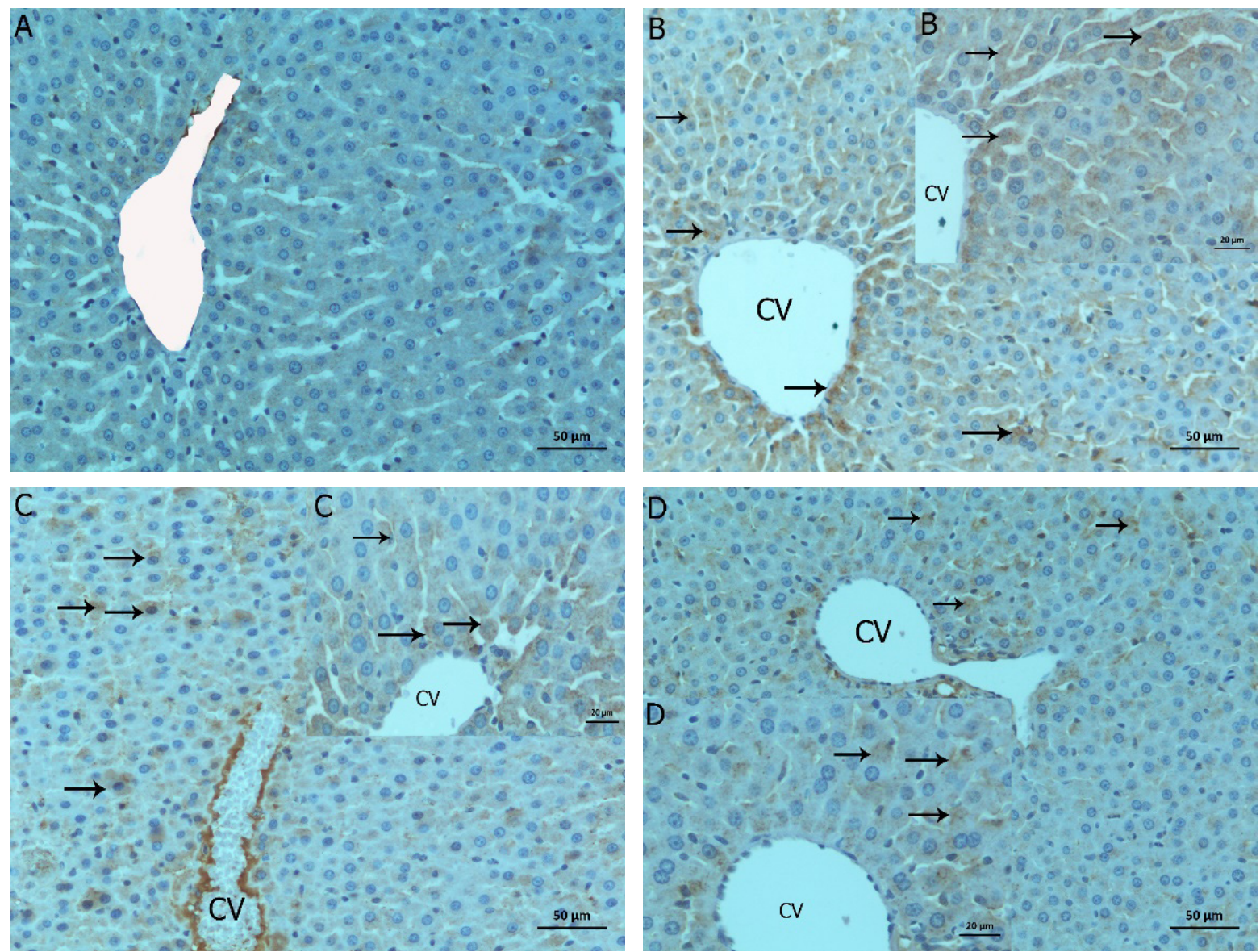

Fig. 2. Immunohistochemical NF-אB staning for control (A) and experimental groups (B, C, D) (arrow: immunpositive cells, CV: Central vein).

le tissue of the clam samples obtained from these regions. Heavy metal accumulation in clam tissue suggests that it may trigger the toxicity in tissues with the frequent consumption of marine based food (Table 1).

As a result of the analyses, it was determined that the $\mathrm{Cd}, \mathrm{Cu}, \mathrm{Pb}$, and $\mathrm{Zn}$ values in sea water were above the upper limit values determined by the Turkish Standards Institute. $\mathrm{Cu}, \mathrm{Pb}$, $\mathrm{Cd}$ levels in sea water samples were found to be higher in Çardak region and $\mathrm{Zn}$ in Çamburnu region. The upper limit values determined by the Turkish Standards Institute and the World Health Organization are shown in Table 1.

It was shown that heavy metal pollution was above the standard values in the regions where sea water analysis data were determined, and the heavy metal concentration was the highest in the Çardak area. In addition, crustacean muscle tissue consumed in diet was found to be below the limit values according to the Turkish Standards Institute (TSI) and World Health Organization (WHO). Cd and $\mathrm{Zn}$ were found below the limit values in the muscle tissue of the groups that received frequent diets and clams daily. The data obtained were in parallel with the results reporting that $\mathrm{Cd}$ and $\mathrm{Zn}$ together increase the toxic effects of each other.

In order to determine the tissue damage that may be caused by heavy metal accumulation and environmental pollution elements (household wastes, chemicals and pesticides, etc.), an ex- 

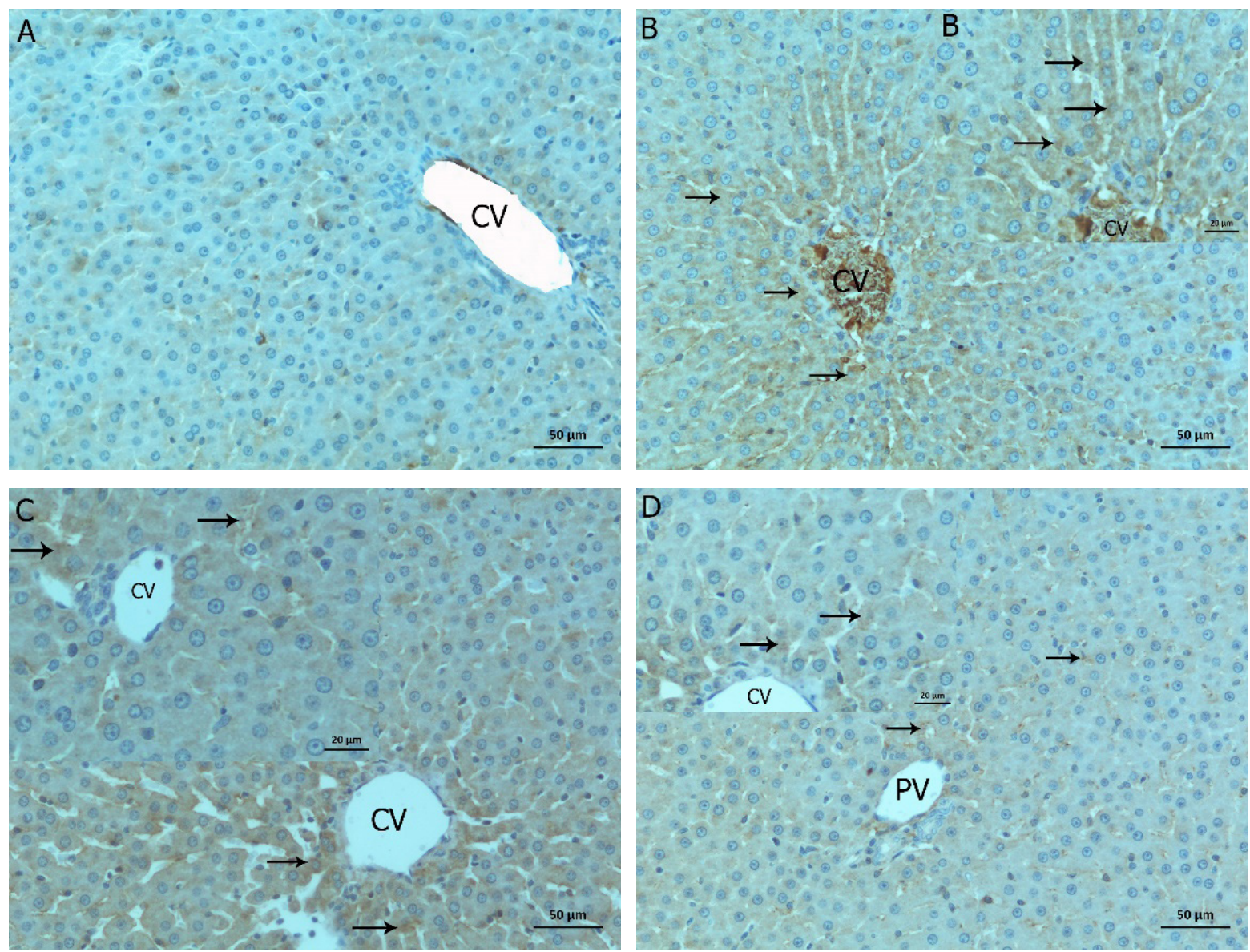

Fig. 3. Immunohistochemical TNF- $\alpha$ staning for control (A) and experimental groups (B, C, D) (arrow: immunpositive cells, CV: Central vein).

Table 1. Heavy metal concentrations of $P$. maximus muscle tissue and seawater in Dardanelles ( $\mu \mathrm{g} / \mathrm{g}$ dry weight and $\mu \mathrm{g} / \mathrm{L}$ seawater)

\begin{tabular}{lcccc}
\hline $\begin{array}{l}\text { Region \& Heavy metal concentrations in } \\
\text { muscle tissue/seawater }\end{array}$ & $\mathbf{C d}$ & $\mathbf{P b}$ & $\mathbf{C u}$ & $\mathbf{Z n}$ \\
\hline Camburnu & $1.11 \pm 0.23^{1}$ & $0.72 \pm 0.45^{1}$ & $1.40 \pm 0.3^{1}$ & $20.74 \pm 3.4^{1}$ \\
& $1.62 \pm 0.28^{\mathrm{a}}$ & $0.91 \pm 0.22^{\mathrm{a}}$ & $2.04 \pm 0.32^{\mathrm{a}}$ & $44.02 \pm 4.89^{\mathrm{a}}$ \\
\hline \multirow{2}{*}{ Lâpseki } & $1.6 \pm 0.5^{1}$ & $0.9 \pm 0.47^{1}$ & $1.54 \pm 0.28^{1}$ & $22.86 \pm 4.01^{1}$ \\
& $1.74 \pm 0.66^{\mathrm{a}}$ & $0.92 \pm 0.44^{\mathrm{a}}$ & $2.35 \pm 0.7^{\mathrm{a}}$ & $42.01 \pm 5.12^{\mathrm{a}}$ \\
\hline \multirow{2}{*}{ Cardak } & $1.4 \pm 0.42^{1}$ & $0.83 \pm 0.38^{1}$ & $1.46 \pm 0.32^{1}$ & $22.24 \pm 4.36^{1}$ \\
& $1.77 \pm 0.45^{\mathrm{a}}$ & $0.960 \pm 0.35^{\mathrm{a}}$ & $2.56 \pm 0.82^{\mathrm{a}}$ & $41.56 \pm 4.47^{\mathrm{a}}$ \\
\hline \multirow{2}{*}{ Average value } & $1.37 \pm 0.36^{1}$ & $0.81 \pm 0.43^{1}$ & $1.46 \pm 0.3^{1}$ & $21.33 \pm 3.92^{1}$ \\
Limit value $(\mu g / g) * *$ & $1.71 \pm 0.75^{\mathrm{a}}$ & $0.93 \pm 0.36^{\mathrm{a}}$ & $2.31 \pm 0.6^{\mathrm{a}}$ & $42.3 \pm 4.83^{\mathrm{a}}$ \\
\hline \multirow{2}{*}{ Limit value $(\mathbf{m g} / \mathbf{L}) *$} & $1^{1}$ & $1^{1}$ & $5^{1}$ & $20^{1}$ \\
& $0.01^{\mathrm{a}}$ & $0.10^{\mathrm{a}}$ & $0.01^{\mathrm{a}}$ & $0.10^{\mathrm{a}}$ \\
\hline
\end{tabular}

*Turkish Standards Institution; **World Health Organization/ United States Environmental Protection Agency; ${ }^{1}$ Muscle tissue

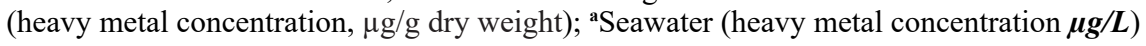



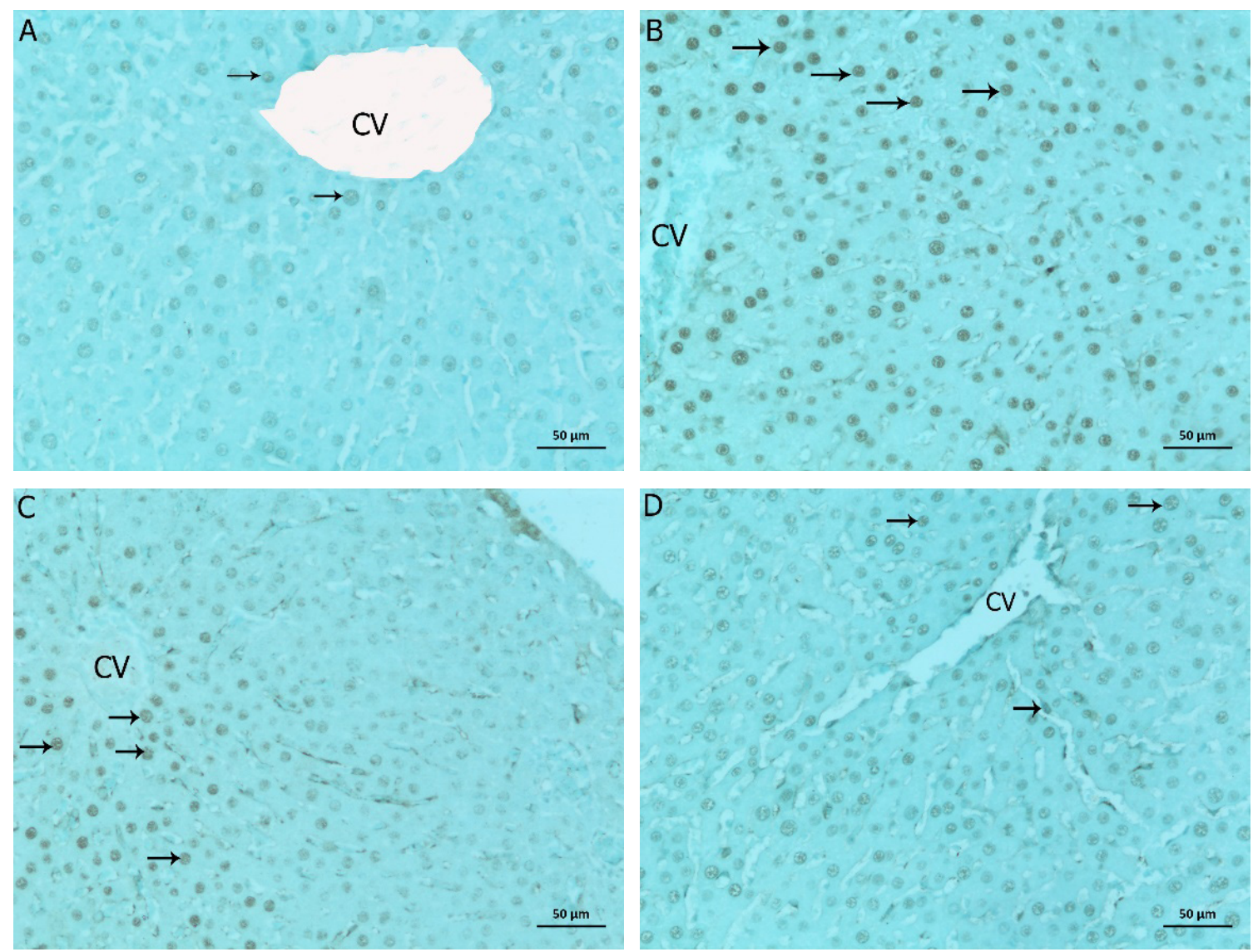

Fig. 4. TUNEL staning for control (A) and experimental groups (B, C, D) (arrow: apoptotic cells, CV: Central vein).

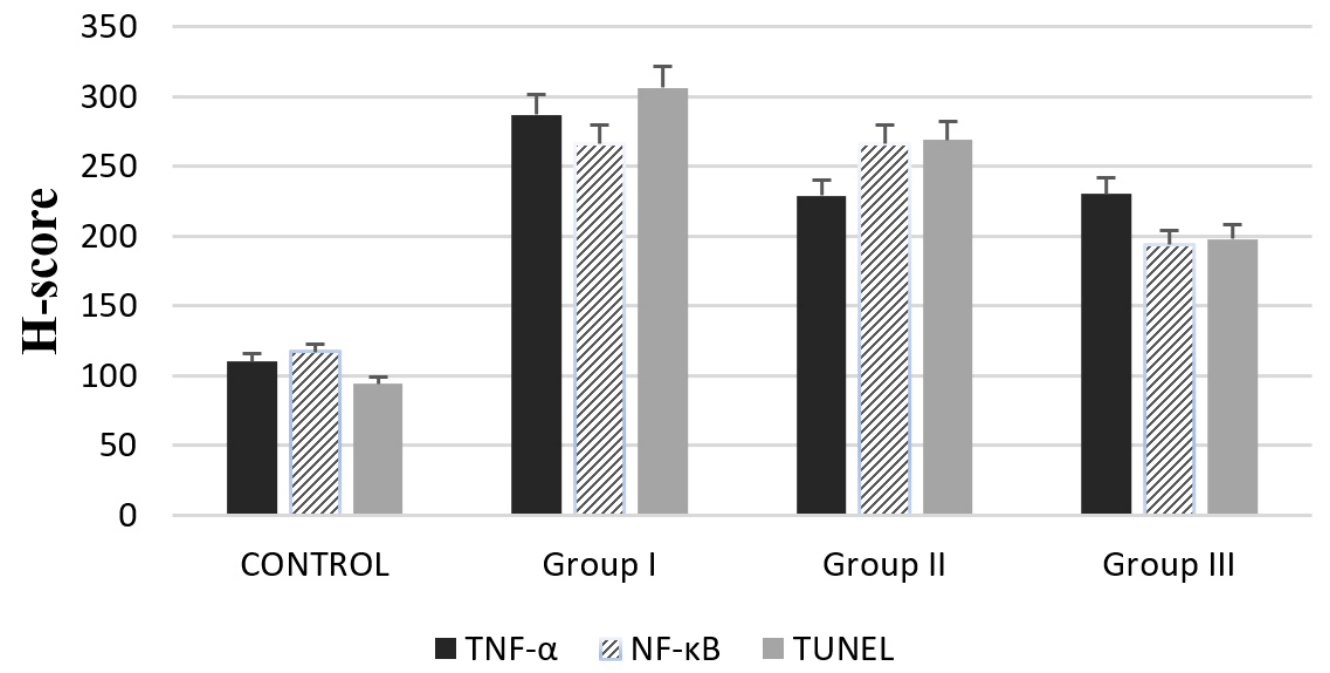

Fig. 5. Immunoreactivity distribution of NF- $\kappa B$, TNF- $\alpha$ and TUNEL reactivity in liver tissues of groups (Control vs G1 ****p<0.0001 Control vs G2 ***p<0.001, Control vs G3**p<0.01, G2 vs G3 *p<0.05). 
perimental model was created. Clams collected from the Dardanelles were given to rats with the mix of standard rat food at different intervals for each group for thirty days.

Dardanelles is polluted by the wastewater of industrial plants, small-sized foundation, and sewage. Also it has been polluted by transit ship crossing the waters. This region is the current of the wastewaters carried from the Black Sea and Marmara Sea. However, it has been stated that the pollution carried by the surface currents over the Dardanelles to the Mediterranean is higher than of the Black Sea. It has been determined that the seawater heavy metal analysis values obtained from the locations are not much different from previous studies $(14,15)$. It was observed that the pollution in the areas where the clam samples were collected increased, and, as a result, consumption of clams from these regions caused tissue damage in the rat liver.

The presence of heavy metals such as zinc and copper in water increases the toxic effect of cadmium. For the protection of aquatic life, it has been suggested that the maximum cadmium concentration in surface water environments should be $0.001 \mathrm{mg} / \mathrm{l}$ (Table 1). Cadmium and zinc are generally found together geologically. Mollusks are particularly inclined to cadmium storage. These creatures store large amounts of cadmium (more than $30 \mathrm{mg} / \mathrm{kg}$ ) in their intestines. As in fish, the amount is very low in their muscles. For this reason, the intestines should be removed immediately after being caught. Because, if not removed, there is a migration from the intestines to the muscle tissue, which prevents the value in the muscles to be drawn to the limit values (16). Previous studies on mussels that had been exposed to heavy metals for a long time and then analyzed by taking various tissues from mussels have reported that these organisms can accumulate these heavy metals in tissues, including muscle, excretory, or even genital organs
$(17,18)$. Analysis results for the muscle tissue of the clam determined that the heavy metal accumulation was above the reference limits. Another experimental study reported that atherosclerosis develops in the vessels due to lipid accumulation in rats fed with mussels grown in contaminated water (19). There is a similarity between the results presented in the previous studies and our study results. Because the nutrition form of the shellfish are filtering, the toxic products, for example heavy metals, can be accumulated in shellfish tissues and caused damage. Therefore, with the consumption of these organisms, these harmful substances can be transferred to the next step by the food chain, thus increasing the tissue damage.

Changing rates of hepatocyte damage, necrosis, lobular and portal inflammation are observed in hepatocellular damage. Balloon degeneration and apoptotic bodies, as well as focal necrosis foci, and inflammatory cells, including neutrophils and eosinophils, are observed in hepatocytes $(20,21)$. In this study, balloon degeneration, portal and lobular fissures in hepatocytes are similar to the literature in toxic liver damage. Also necrosis was detected, along with inflammation in the lobule and portal areas. Balloon degeneration is much more common in the group fed with clams on a daily basis (G1). Our balloon degeneration and necrosis results suggest that clam may show cytotoxic effects in mixed forms. Thus, the source of histopathological damage occurring in the liver is due to the transition of heavy metals by toxic effects from clams.

Liver injuries triggered by hemorrhagic shock, the protein supplements obtained from the crustaceans decrease the damage, and the level of inflammatory marker TNF- $\alpha$ (22). TNF- $\alpha$ plays a role in the pathophysiology of TNF- $\alpha$, viral hepatitis, alcoholic liver disease, non-alcoholic fatty liver disease, and ischemia-reperfusion injury in the liver. Studies have shown that when the 
degenerative process starts in liver, TNF- $\alpha$ induces synthesis of hepatocytes and Kupffer cells in the cytoplasms (23). This study determined that clam diet caused degeneration of hepatocellular structure and that TNF- $\alpha$ immunoreactivity severed as consumption frequency increased. TNF- $\alpha$, a cytokine secreted for conservation purposes, shows that the damaged structure of the liver can be cleaned by apoptosis, inflammatory changes and re-trigger regeneration. Another study reported that Pacific oyster extract decreased liver fibrosis, and inflammatory markers such as TGF- $\beta$ and NF- $\kappa$ B decreased $(23,24)$. When oxidative stress in tissues associated with damage to cells increases, activation of the TNF- $\alpha$ receptor is followed by activation of the nuclear factor kappa B (NF- $\boldsymbol{\kappa} \boldsymbol{B})$. Thus, NF$\boldsymbol{\kappa} \boldsymbol{B}$ penetrates the nucleus and NF- $\boldsymbol{\kappa} \boldsymbol{B}$ activates genes that try to block TNF-induced apoptosis. In resting cells, NF- $\boldsymbol{\kappa} \mathrm{B}$ is an inactive form in the cytoplasm $(25,26)$. This results in the initiation of inflammatory, immune and, wound-healing responses and clearing of pathogens. Some research has stated that inflammation is not only associated with chronic liver disease, but also actively promotes disease progression. NF- $\kappa \mathrm{B}$ has a wide range of function in different cellular sections, such as the survival of hepatocytes, the secretion of Kupffer cells, secreting cytokines that cause the inflammation. The critical role of NF- $\mathrm{KB}$ in the liver has been reported to steer spontaneous liver damage, fibrosis and hepatocellular carcinoma in the genetic ablation of NF$\kappa \mathrm{B}$ regulators in rat models (27). Results in this study show that, similarly to previous studies, the expression of TNF- $\alpha$ and NF- $\kappa$ B increased in hepatocyte cytoplasms parallel with its regulatory role in liver tissue. As the hepatotoxic effect increased as the frequency consumption of the clam diet increased, TNF- $\alpha$ and NF- $\kappa \mathrm{B}$ expression was observed at the highest level in the G1 experimental group.

\section{Conclusion}

Seafood is among the essential food sources that are frequently consumed. However, such products consumed by humans cause health risks due to being contaminated by many pollutants. Results obtained showed the confirmed parameters that are encountered in many regions and countries around the world, dependeding on the amount of consumption, nutrition habits, and global pollution. It was observed that consumption of clams collected from Dardanelles, caused inflammation and degeneration in tissue of liver. This damage has been caused by the consumption of seafood frequently with high heavy metal content. While paying attention to nutrition with alternative and healthy foods, environmental factors should not be ignored, and harmful nutrients that can cause tissue damage in many systems, especially the digestive and excretory ones, should be avoided bearing in mind that conscious and balanced nutrition is extremely important for our health. There is a greater need for studies that include precautions to prevent health problems related to eating habits and environmental pollution.

\section{Acknowledgment}

This research did not receive any financial support.

\section{Declaration of conflicting interests}

The authors declare that there is no conflict of interest in the publication of this study.

\section{References}

1. Claisse D, Cossa D, Bretaudeau-Sanjuan J, Touchard G, Bombled B. Methylmercury in molluscs along the French coast. Mar. Pollut. Bull. 2001;42:329-32. DOI: 10.1016/S0025-326X(01)00036-4

2. Piló D, Carvalho S, Pereira P, Gaspar MB, Leitão A. Is metal contamination responsible for increasing aneuploidy levels in the Manila clam Ruditapes philippinarum? Science of the Total Environment. 2017;577:340-8. DOI: 10.1016/j.scitotenv.2016.10.193 
3. Ali H, Khan E, Ilahi I. Environmental Chemistry and Ecotoxicology of Hazardous Heavy Metals: Environmental Persistence, Toxicity, and Bioaccumulation. Journal of Chemistry. 2015;6730305:1-14. DOI: $10.1155 / 2019 / 6730305$

4. Blackmore G, Wang WX. The transfer of cadmium, mercury, methylmercury, and zinc in an intertidal rocky shore food chain. J. Exp.Mar. Biol. Ecol. 2004;307:91110. DOI: $10.1016 /$ j.jembe.2004.01.021

5. Kodama K. Lee JH, Oyama M, Shiraishi H, Horiguchi T. Disturbance of benthic macrofauna in relation to hypoxia and organic enrichment in a eutrophic coastal bay. Marine Environmental Research. 2012; 76:80-89. DOI: 10.1016/j.marenvres.2011.08.007

6. Jomova K, Valko M. Advances in metal-induced oxidative stress and human disease. Toxicology. 2011;283(23):65-87. DOI: 10.1016/j.tox.2011.03.001

7. Rani A, Kumar A, Lal A, Pant M. Cellular mechanisms of cadmium-induced toxicity: A review. Int J Environ Heal R. 2014;24(4):378-99. DOI: 10.1080/09603123.2013.835032

8. Koedrith P, Seo YR. Advances in carcinogenic metal toxicity and potential molecular markers. International Journal of Molecular Sciences. 2011;12(12):9576-95. DOI: $10.3390 /$ ijms 12129576

9. Jonathan MP, Mu-oz-Sevilla NP, Góngora-Gómez AM, Luna Varela RG, Sujitha SB. Bioaccumulation of trace metals in farmed pacific oysters Crassostrea gigas from SW Gulf of California coast, Mexico. Chemosphere. 2017;187:311-19. DOI: 10.1016/j.chemosphere.2017.08.098

10. Páez-Osuna F, Osuna-Martínez CC. Bioavailability of cadmium, copper, mercury, lead, and zinc in subtropical coastal lagoons from the southeast Gulf of California using mangrove oysters (Crassostrea corteziensis and Crassostrea palmula). Arch Environ Contam Toxicol. 2015;68(2): 305-16. DOI: 10.1007/s00244-014-0118-3

11. Gürpınar TN, Ekerbiçer N, Uysal BT, Tarakçı F, Tuglu MI. The effects of the melatonin treatment on the oxidative stress and apoptosis in diabetic eye and brain. Scientific World Journal. 2012;2012: 498489. DOI: 10.1100/2012/498489

12. Öztürk Ş, Kılıçaslan Sönmez P, Özdemïr İ, Topdağ1 Y, Tuğlu M. Kemik iliği kaynaklı mezenkimal kök hücrelerin deneysel Asherman modeli üzerine antiapoptotik ve proliferatif etkisi. Cukurova Medical Journal. 2019;44:434-46. DOI: 10.17826/cumj.573200

13. Numata M, Morinaga S, Watanabe T, Tamagawa H, Yamamoto N, Shiozawa M. The clinical significance of SWI/SNF complex in pancreatic cancer. International Journal of Oncology. 2013; 42:403-10. DOI: 10.3892/ ijo. 2012.1723
14. Ustunada M, Erduğan H, Y1lmaz S, Akgul R, Aysel V. Seasonal concentrations of some heavy metals $(\mathrm{Cd}, \mathrm{Pb}$, $\mathrm{Zn}$, and $\mathrm{Cu}$ ) in Ulva rigida J. Agardh (Chlorophyta) from Dardanelles (Canakkale, Turkey). Environmental Monitoring and Assessment. 2011;77(1):337-42. DOI: 10.1007/s10661-010-1637-7

15. Metian M, Warnau M, Cosson R, Oberhänsli F. Bioaccumulation and detoxification processes of $\mathrm{Hg}$ in the king clam Pecten maximus: Field and laboratory investigations. Aquatic toxicology. 2008;90:204-13. DOI: 10.1016/j.aquatox.2008.08.014

16. Oehlenschläger J (2002). Identifying heavy metals in fish. Safety and Quality Issues in Fish Processing Edited by: Bremner, H.A. Woodhead Publishing, 95-113 s, England. DOI: 10.1533/9781855736788.1.95

17. Sánchez-Marín P, Durán R, Beiras R. In vivo oral bioavailability of $\mathrm{Pb}$ sequestered in metal rich granules in bivalves. Ecotoxicol Environment Saf. 2019;181:3305. DOI: 10.1016/j.ecoenv.2019.06.021

18. Moore MN, Shaw JP, Pascoe C, Beesley A, Viarengo A, Lowe DM. Anti-oxidative hormetic effects of cellular autophagy induced by nutrient deprivation in a molluscan animal model. Marine Environmental Research. 2020;156:104903. DOI: 10.1016/j.marenvres.2020.104903

19. Gorinstein S, Leontowicz M, Leontowicz H, Namiesnik J, Jastrzebski Z, Drzewiecki J, et al. Influence of mussels (Mytilus galloprovincialis) from polluted and non-polluted areas on some atherosclerosis indices in rats fed cholesterol. Food chemistry. 2008;111(2):3816. DOI: 10.1016/j.foodchem.2008.03.082

20. Mantovani A, Allavena P, Sica A, Balkwill F. Cancer-related inflammation. Nature. 2008;454(7203):43644. DOI: 10.1038/nature07205

21. David S, Hamilton JP. Drug-induced Liver Injury. US Gastroenterol Hepatol Rev. 2010;6:73-80.

22. Lee RP, Subeq YM, Lee CJ, Hsu BG, Peng TC. Freshwater clam extract decreased hemorrhagic shock-induced liver injury by attenuating TNF- $\alpha$ production. Biological Research for Nursing. 2012;14(3):286-93. DOI: $10.1177 / 1099800411408881$

23. Kalliolias GD, Ivashkiv LB. TNF biology, pathogenic mechanisms and emerging therapeutic strategies. Nature reviews. Rheumatology. 2016;12(1):49-62. DOI: 10.1038/nrrheum.2015.169

24. Zhou J, Liang Y, Pan JX, Wang FF, Lin XM, Ma RJ. Protein extracts of Crassostrea gigas alleviate $\mathrm{CCl}_{4}$-induced hepatic fibrosis in rats by reducing the expression of CTGF, TGF- $\beta 1$ and NF- $\mathrm{KB}$ in liver tissues. Molecular Medicine Reports. 2015;11(4): 2913-20. DOI: 10.3892/mmr.2014.3019

25. Karin M. Nuclear factor-kappaB in cancer develop- 
ment and progression. Nature. 2006;441: 431-6. DOI: 10.1038 /nature 04870

26. Schattenberg JM, Schuchmann M. Diabetes and apoptosis: liver. Apoptosis. 2009;14:1459-71. DOI: 10.1007/ s10495-009-0366-2

27. Kosters A, Karpen SJ. The role of inflammation in cholestasis: clinical and basic aspects. Semin Liver Dis. 2010;30:186-94. DOI: 10.1055/s-0030-1253227 